\title{
Integrated Use of Residues from Olive Mill and Winery for Lipase Production by Solid State Fermentation with Aspergillus sp.
}

\author{
José Manuel Salgado • Luís Abrunhosa • \\ Armando Venâncio • José Manuel Domínguez • \\ Isabel Belo
}

Received: 26 August 2013 / Accepted: 28 October 2013 /

Published online: 27 November 2013

(C) Springer Science+Business Media New York 2013

\begin{abstract}
Two-phase olive mill waste (TPOMW) is presently the major waste produced by the olive mill industry. This waste has potential to be used as substrate for solid state fermentation (SSF) despite of its high concentration of phenolic compounds and low nitrogen content. In this work, it is demonstrated that mixtures of TPOMW with winery wastes support the production of lipase by Aspergillus spp. By agar plate screening, Aspergillus niger MUM 03.58, Aspergillus ibericus MUM 03.49, and Aspergillus uvarum MUM 08.01 were chosen for lipase production by SSF. Plackett-Burman experimental design was employed to evaluate the effect of substrate composition and time on lipase production. The highest amounts of lipase were produced by A. ibericus on a mixture of TPOMW, urea, and exhausted grape mark (EGM). Urea was found to be the most influent factor for the lipase production. Further optimization of lipase production by A. ibericus using a full factorial design $\left(3^{2}\right)$ conducted to optimal conditions of substrate composition ( $0.073 \mathrm{~g}$ urea/g and $25 \%$ of EGM) achieve $18.67 \mathrm{U} / \mathrm{g}$ of lipolytic activity.
\end{abstract}

Keywords Olive mill wastes · Winery wastes · Plackett-Burman · Solid state fermentation · Aspergillus sp.

\section{Introduction}

Wineries and olive oil industries are dominant agro-industrial activities in southern European regions. Mediterranean countries produce around $98 \%$ of the world's olive oil, which was estimated at 3.4 million metric tons in 2011/2012 crop year (IOOC, 2012). The European Union (EU) countries produce around $74 \%$ of the global olive oil production, being the largest

J. M. Salgado $\cdot$ L. Abrunhosa $\cdot$ A. Venâncio $\cdot$ I. Belo $(\bowtie)$

IBB-Institute for Biotechnology and Bioengineering, Centre of Biological Engineering, University of Minho, Campus de Gualtar, 4710-057 Braga, Portugal

e-mail: ibelo@ceb.uminho.pt

J. M. Domínguez

Department of Chemical Engineering, Sciences Faculty, University of Vigo (Campus Ourense), As Lagoas s/n, 32004 Ourense, Spain 
olive oil producers are Spain with $60 \%$, Italy with $22 \%$, and Greece with $15 \%$ of the EU's total production (IOOC, 2012). Concerning the production of wine, world production reached 265 million hectoliters in 2010 (OIV, 2012).

In olive mills, different wastes are generated according to extraction systems. Three systems are used for oil extraction from olives: (1) the traditional press cake system, (2) the three-phase decanter system, and (3) the more recent two-phase centrifugation system [1]. Two residues are generated in three-phase systems, olive cake, and olive mill wastewater (OMWW). OMWW causes major environmental problems due to high organic load and high content of phenolic compounds which hinder bioremediation treatments [2]. Therefore, olive oil industries tend to shift to the two-phase system in order to reduce water consumption and to avoid OMWW. However, these systems produce an olive pomace called two-phase olive mill waste (TPOMW) that also needs to be properly treated before being disposed. TPOMW consist of a thick sludge that contains water, pieces of olive stone, and the pulp of olive fruit [1]. Its management and transport is hampered by its high moisture content. Additionally, its disposal by combustion processes is not attractive because the energy obtained does not exceeds greatly the energy consumed for drying TPOMW [3]. In Spain, TPOMW production reached approximately 5.2 million tons in 2009. In Portugal, only $33 \%$ of the olive mills use the two-phase process but they produce $80 \%$ of the Portuguese olive oil [4]. These data show that alternative applications for this residue need to be investigated [5].

In wineries, the main wastes are grape mark and wine lees. These residues are commonly sent to alcohol distilleries producing exhausted grape mark (EGM) and vinasses as byproducts (V) [6]. The winery and distillery residues present a low $\mathrm{pH}$, high $\mathrm{COD}$, and phenolic compounds [6]. Both wineries and olive oil industries generate their wastes in the same period of the year (August-December) and they are common agro-industries in Mediterranean countries and other parts of the world [7].

Solid state fermentation (SSF) is a fermentation process occurring in absence or nearabsence of free water that employs natural substrates or an inert substrate as solid support [8]. SSF has many advantages such as lower energy requirement and less wastewater [9]. Whenever solid substrate serves both as a support and a nutrient source, a pretreatment is needed to allow the microorganism to growth. Size reduction by grinding; rasping or chopping; homogenization; physical, chemical, or enzymatic hydrolysis; cooking; or vapor treatments are the most common ones [10].

The use of by-products of agro-food industries as TPOMW or EGM could avoid the application of these pretreatments, as these raw materials have already been subjected to many processing steps. Waste mixtures are often used as substrate for SSF [11, 12]. However, no works have been reported on wineries and olive mill waste mixtures.

The use of olive pomace for the production of enzymes by SSF has been studied, notably for lipases [13, 14], since the remaining olive oil induce their production [15]. However, TPOMW has been investigated for this purpose to a lesser extent. Aloui et al. [16] evaluate detoxification processes of TPOMW by SSF with different fungi. A treatment of TPOMW by SSF with Paecilomyces variotii was developed to produce lysine and to increase protein content in order to obtain a product that has the potential to be used as animal feed [17].

Filamentous fungi have the ability of growing on solid substrate and can produce several extracellular enzymes [18]. Black aspergilli (Aspergillus section Nigri) are used in the fermentation industry to produce hydrolytic enzymes, such as amylases or lipases [19]. Aspergillus niger is a species widely studied in SSF process for citric acid and enzymes production such as biomass-degrading enzymes production [20]. Aspergillus uvarum is a black Aspergillus isolated from grape berries in the Mediterranean area [19]. It was found to be related to Aspergillus japonicus based on morphological data [19]. Unlike A. niger, no studies on 
enzymes production by SSF with $A$. uvarum are available. However, A. japonicus isolated from olive mill wastes showed lipolytic and cellulolytic activity [21]. Aspergillus ibericus is a new species isolated from wine grapes [22]. It was able to produce lipases in submerged fermentation $(\mathrm{SmF})$ using OMWW as substrate [4].

In this paper, we report a screening survey on the production of extracellular lipases by different filamentous fungi and an evaluation of the potential use of wastes from wineries and olive oil mills as substrates for lipase production by selected fungi using SSF. The optimization of the fermentation medium for the most promising species, A. ibericus, using a full factorial design is also reported.

\section{Materials and Methods}

\section{Raw Material}

The waste samples were collected from industries in the area in season 2011/2012 and stored at $-20{ }^{\circ} \mathrm{C}$. The solid residues were TPOMW, EGM, and vineshoot trimmings (VT). The liquid wastes were $\mathrm{V}$ and OMWW. Nitrogen and carbon in solid residues were analyzed using a Thermo Finningan Flash Elemental Analyzer 1112 series, San Jose, CA (USA). Free reducing sugars, total phenols, and proteins in solid residues were measured after extraction with water 1:5 $(w / v)$. Reducing sugars were determined by dinitrosalicylic acid method. Lipids (total fat contents) were extracted with diethyl ether, in a Soxtec System HT2 1045-extraction unit. Protein was analyzed by Bradford method. Total phenols were measured by the FolinCiocalteu method using caffeic acid as standard. Total nitrogen in liquid residues was determined by the test kit from Hach Lange LCK 338. For COD determination, the test kit from Hach Lange LCK914 was used according the manufacturer method. Total organic carbon (TOC) in liquid residues was quantified by the test kit from Hach Lange LCK 387. Total solids were analyzed by oven-dried to constant weight at $102{ }^{\circ} \mathrm{C}$.

The standardized solid wastes possessed the following characteristics (mean values $\pm \mathrm{SD}$; $n=3$ ), TPOMW: C, $516.61 \pm 15.43 \mathrm{~g} / \mathrm{kg} ; \mathrm{N}, 8.59 \pm 1.92 \mathrm{~g} / \mathrm{kg}$; reducing sugars, $24.30 \pm$ $1.42 \mathrm{mg} / \mathrm{g}$; protein, $0.3 \pm 0.03 \mathrm{mg} / \mathrm{g}$; total phenols, $2.57 \pm 0.04 \mathrm{mg} / \mathrm{g}$; lipids, $102.46 \pm$ $0.04 \mathrm{mg} / \mathrm{g}$. The composition of EGM was as follows: C, $482.37 \pm 16.07 \mathrm{~g} / \mathrm{kg} ; \mathrm{N}, 16.97 \pm$ $6.26 \mathrm{~g} / \mathrm{kg}$; reducing sugars, $3.00 \pm 0.01 \mathrm{mg} / \mathrm{g}$; protein, $1.3 \pm 0.01 \mathrm{mg} / \mathrm{g}$; total phenols, $0.19 \pm$ $0.01 \mathrm{mg} / \mathrm{g}$; lipids, $21.30 \pm 0.01 \mathrm{mg} / \mathrm{g}$. VT composition was the following: C, $453.56 \pm 2.21 \mathrm{~g} / \mathrm{kg}$; $\mathrm{N}, 5.62 \pm 0.71 \mathrm{~g} / \mathrm{kg}$; reducing sugars, $55.35 \pm 0.05 \mathrm{mg} / \mathrm{g}$; protein, $1.27 \pm 0.03 \mathrm{mg} / \mathrm{g}$; total phenols, $1.25 \pm 0.04 \mathrm{mg} / \mathrm{g}$; lipids, $29.60 \pm 0.01 \mathrm{mg} / \mathrm{g}$.

The standardized effluents possessed the following characteristics (mean values $\pm \mathrm{SD} ; n=3$ ), $\mathrm{V}: \mathrm{N}, 218.67 \pm 35.27 \mathrm{mg} / \mathrm{L}$; TOC, $3.53 \pm 0.02 \mathrm{~g} / \mathrm{L}, \mathrm{COD}, 48.07 \pm 1.43 \mathrm{~g} / \mathrm{L}$; reducing sugars, $0.68 \pm 0.01 \mathrm{~g} / \mathrm{L}$; protein, $0.31 \pm 0.08 \mathrm{~g} / \mathrm{L}$; lipids, not detected; total phenols, $0.54 \pm 0.03 \mathrm{~g} / \mathrm{L}$; total solids, $2.24 \pm 0.09 \%$. OMWW composition was as follows: N, $5.20 \pm 0.21 \mathrm{mg} / \mathrm{L}$; TOC, $21.40 \pm$ $1.20 \mathrm{~g} / \mathrm{L}, \mathrm{COD}, 122.90 \pm 0.42 \mathrm{~g} / \mathrm{L}$; reducing sugars, $12.72 \pm 1.31 \mathrm{~g} / \mathrm{L}$; protein, $0.04 \pm 0.01 \mathrm{mg} / \mathrm{L}$; lipids, $4.11 \pm 0.42 \mathrm{~g} / \mathrm{L}$; total phenols, $5.91 \pm 0.09 \mathrm{~g} / \mathrm{L}$; total solids, $15.43 \pm 0.51 \%$.

\section{Microorganisms}

Representative strains of the most common black Aspergillus species were used and are listed in Table 1. Strains were obtained from MUM culture collection (University of Minho, Braga, Portugal). They were revived on malt extract agar (MEA) plates ( $2 \%$ malt extract, $2 \%$ glucose, $0.1 \%$ peptone, and $2 \%$ agar) from preserved glycerol stocks stored at $-80{ }^{\circ} \mathrm{C}$. Then subcultured 
Table 1 Screening of filamentous fungi for extracellular enzymes

\begin{tabular}{lllll}
\hline Fungi & Code & $\begin{array}{l}\text { Proteolytic } \\
\text { activity }\end{array}$ & $\begin{array}{l}\text { Lipolytic activity } \\
\text { (tributyrin) }\end{array}$ & $\begin{array}{l}\text { Lipolytic activity } \\
\text { (Rhodamine) }\end{array}$ \\
\hline A. niger & MUM 03.58 & ++ & ++ & ++ \\
A. niger & 01UAs83 & + & + & ++ \\
A. niger & $01 \mathrm{UAs} 181^{\mathrm{a}}$ & - & + & ++ \\
A. niger & $01 \mathrm{UAs} 107^{\mathrm{a}}$ & - & + & ++ \\
A. foetidus & 01UAs162 & - & - & ++ \\
A. tubingensis & MUM 06.152 & + & ++ & ++ \\
A. uvarum & MUM 08.01 & ++ & + & ++ \\
A. ibericus & 03UAs268 & - & - & ++ \\
A. ibericus & MUM 03.49 & - & ++ & ++ \\
A. ibericus & 03UAs91 & - & ++ & ++ \\
A. ibericus & 03UAs113 & - & - & ++ \\
\hline
\end{tabular}

Data collected after 5 days of growth

+ positive, halo $<2 \mathrm{~cm},++$ positive, ring $2-4 \mathrm{~cm},+++$ positive, ring $>4 \mathrm{~cm}$, - without ring

${ }^{\mathrm{a}}$ Isolation codes

on MEA slants and incubated at $25{ }^{\circ} \mathrm{C}$ for 7 days to obtain inoculum for SSF. During the experimental period, strains were preserved at $4{ }^{\circ} \mathrm{C}$ and cultured monthly on fresh MEA slants.

\section{Fungi Selection Assay}

Fungal strains were screened for their ability to produce extracellular lipases and proteases. Culture medium to determine enzymatic activity on solid agar plates was prepared by adding $3 \mathrm{~g} / \mathrm{L} \mathrm{NaNO}_{3}, 1 \mathrm{~g} / \mathrm{L} \mathrm{K}_{2} \mathrm{HPO}_{4}, 0.5 \mathrm{~g} / \mathrm{L} \mathrm{KCl}, 0.5 \mathrm{~g} / \mathrm{L} \mathrm{MgSO} \mathrm{M}_{4} \cdot 7 \mathrm{H}_{2} \mathrm{O}, 0.5 \mathrm{~g} / \mathrm{L} \mathrm{CaCl}{ }_{2} \cdot 2 \mathrm{H}_{2} \mathrm{O}$, $1 \mathrm{~mL} / \mathrm{L}$ metal solution $\left(10 \mathrm{~g} / \mathrm{L} \mathrm{ZnSO}_{4} \cdot 7 \mathrm{H}_{2} \mathrm{O}, \mathrm{CuSO}_{4} \cdot 5 \mathrm{H}_{2} \mathrm{O}, \mathrm{FeSO}_{4} \cdot 7 \mathrm{H}_{2} \mathrm{O}\right), 0.1 \mathrm{~mL} / \mathrm{L}$ Triton $\mathrm{X}-100,20 \mathrm{~g} / \mathrm{L}$ agar, and substrate for each enzymatic activity determination. All media were adjusted to $\mathrm{pH} 5.6$ and autoclaved at $121{ }^{\circ} \mathrm{C}$ for $15 \mathrm{~min}$. After, $20 \mathrm{~mL}$ of medium was poured into sterile Petri plate and allowed to solidify. The fungal cultures were inoculated at the center of plate containing sterile medium and incubated at $25^{\circ} \mathrm{C}$ during 5 days.

Two methods were tested to determine lipase activity. A fluorescence lipase assay that is based on the interaction of Rhodamine B with fatty acid released during the enzyme hydrolysis of olive oil [23] and the tributyrin method. Rhodamine B $(10 \mathrm{~mL} / \mathrm{L})$ and olive oil $(25 \mathrm{~g} / \mathrm{L})$ were added to medium previously described. Petri plates were observed every day under UV light at $350 \mathrm{~nm}$. Lipase activity was detected by orange fluorescence halo around the colony. In tributyrin method, $10 \mathrm{~g} / \mathrm{L}$ of tributyrin was added as substrate along with the described medium. Lipolytic activity was identified by clear zone of medium around the colony.

To measure proteolytic activity, $10 \mathrm{~g} / \mathrm{L}$ of powdered skimmed milk was added to the described medium. Proteolytic activity was detected by the appearance of clear zone of medium around growth colony.

\section{Solid State Fermentation}

Fermentations were carried out in Erlenmeyer flask of $500 \mathrm{~mL}$ with $30 \mathrm{~g}$ of dry solid substrate. Compositions of media were defined in Table 2. Moisture level was adjusted to $75 \%$ (wet 


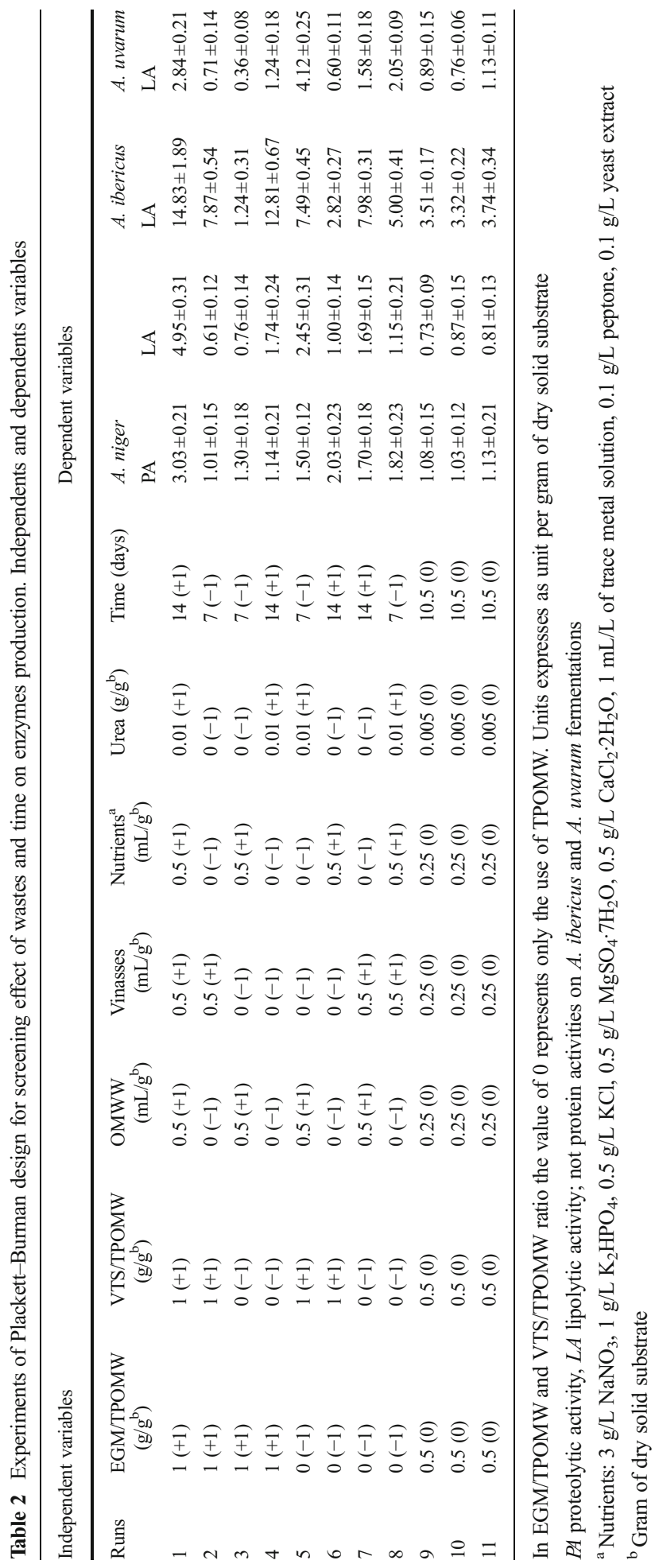


basis). Erlenmeyer with substrate were sterilized at $121^{\circ} \mathrm{C}$, for $15 \mathrm{~min}$. Independent fermentations were performed with $A$. niger, $A$. ibericus, and $A$. uvarum. For the inoculation, spores of fungus grown in MEA medium slant tubes were suspended in a sterilized solution composed by $0.1 \%$ of peptone and $0.01 \%$ of Tween 80 . The inoculum spore concentration was adjusted to $10^{6}$ spores $/ \mathrm{mL}$ using a Neubauer counting chamber. Each flask was inoculated with $2 \mathrm{~mL}$ of the spore suspension and incubated at $25^{\circ} \mathrm{C}$ for 7 or 14 days.

The extraction of enzymes was performed at the end of each experiment (7 or 14 days) with a solution composed of $1 \% \mathrm{NaCl}$ and $0.5 \%$ Triton $\mathrm{X}-100$ at $4{ }^{\circ} \mathrm{C}$ in a solid/liquid ratio of $1: 5$, and $2 \mathrm{~h}$ of stirring. Following, extracts were centrifuged $(12,225 \times \mathrm{g}, 10 \mathrm{~min})$ and filtered through Whatman no. 1 filter paper.

\section{Plackett-Burman Experimental Design}

The Plackett-Burman experimental design is a statistical approach chosen to evaluate the effect of mixtures of olive mills and winery wastes on the lipases and proteases production by SSF, seven independent variables were screened in eight combinations (Table 2). PlackettBurman design is a fraction of a two-level factorial design and allows investigation of $n-1$ variables with at least $n$ experiments. In addition, three center points were added to the eight experiments to ensure enough degrees of freedom for error evaluation. Experiments were carried out in randomize order to avoid protection against the effects of lurking variables. This design assumes that there are no interactions between the different media components $\left(x_{i}\right)$ in the range of variables under consideration. The following first-order polynomial model was used to describe the results (Eq. 1):

$$
Y=\beta_{0}+\sum \beta_{i} \cdot x_{i}+\varepsilon
$$

Where $Y$ is the response value, $\beta_{0}$ is the model intercept, $\beta_{i}$ is the linear coefficient, $x_{i}$ is the level of the independent variable, and $\varepsilon$ is the curvature effect.

The factors were as follows: addition of EGM, VTS, OMWW, V, nutrients, urea, and fermentation time. Lipase and protease activities were taken as the responses. The factors that have confidence level above $95 \%$ were considered the most significant factors affecting enzyme production. The main effect of the substrate composition, regression coefficients, $P$ values, and correlation coefficients were determined using Statistica version 5.0 (Statsoft, USA).

\section{Full Factorial Design}

To optimized lipase production full factorial design was planned. The two variables that presented higher effect on lipase production in previously Plackett-Burman design were selected to test on three levels in a $3^{2}$ full factorial design. This design allows estimating the significance of parameters and their interaction using Student's $t$ tests. The experimental design was performed in 11 experiments with three replicates in the center point. For statistical calculation, the variables were coded according to Eq. 2:

$$
x_{i}=\left(\mathrm{X}_{1}-\mathrm{X}_{0}\right) / \delta X
$$

where, $x_{i}$ is the dimensionless coded value of the independent variable, $X_{0}$ is the value of independent variable at the center point, and $\delta X$ is the step change. 
The interrelationship between dependent and independent variables was established by Eq. 3:

$$
Y=b_{0}+b_{1} x_{1}+b_{2} x_{2}+b_{3} x_{3}+b_{12} x_{1} x_{2}+b_{11} x_{1}^{2}+b_{22} x_{2}^{2}
$$

where $y$ is predicted response, $b_{0}$ is the model constant, $x_{1}$ and $x_{2}$ are independent variables (coded), $b_{1}$ and $b_{2}$ are linear coefficients, $b_{12}$ is cross-product coefficient, and $b_{11}$ and $b_{22}$ are the quadratic coefficients. The experimental data were evaluated by response surface methodology using Statistica 5.0 software. Dependent variable was optimized using an application of commercial software (Solver, Microsoft Excel 2007, Redmon, WA, USA).

\section{Lipase Activity}

Lipolytic activity was determined in the extract solutions from SSF. A spectrophotometric method was carried out using $p$-nitrophenyl-butyrate in sodium acetate buffer $50 \mathrm{mM}$ (pH 5.6) as substrate. The reaction mixture was incubated at $37{ }^{\circ} \mathrm{C}$ for $15 \mathrm{~min}$ and stopped by addition of acetone [24]. The absorbance was measured at a wavelength at $405 \mathrm{~nm}$. A blank without enzymatic extract was performed in each analysis. One unit of activity was defined as the amount of enzyme required to release $1 \mu \mathrm{mol}$ of $p$-nitrophenol per minute, under the assay conditions. Lipase activity was reported in terms of units per gram of dry substrate in SSF.

\section{Protease Activity}

Protease activity was quantified by spectrophotometric method [25] which is based on the reaction of $0.5 \mathrm{~mL}$ of SSF extracts with $0.5 \mathrm{~mL}$ of $0.5 \%(w / v)$ azocasein in acetate buffer $50 \mathrm{mM}(\mathrm{pH} 5)$ at $37^{\circ} \mathrm{C}, 40 \mathrm{~min}$. After incubation, $10 \%(w / v)$ trichloroacetic acid was added to precipitate residual protein not hydrolyzed by the proteolytic enzymes. The sample was centrifuged $(3,000 \times \mathrm{g}, 5 \mathrm{~min})$ and a solution of potassium hydroxide $5 \mathrm{~N}$ was added to the supernatant, producing a pinky-orange color. The intensity of this coloration was measured at a wavelength of $428 \mathrm{~nm}$. The blank was performed under the same conditions, but adding trichloroacetic acid before incubation. One unit of proteolytic activity was defined as the amount of enzyme that produced an increase of 0.01 of absorbance relatively to the blank per minute, under the assay conditions.

\section{Biomass Estimation}

The growth of fungi was estimated by ergosterol content measurements. A modification of the method by Mar et al. [26] was applied. The extraction of fungal colony from SSF was performed by mixing $20 \mathrm{~mL}$ of $\mathrm{KOH}(10 \%$ in methanol) with $1 \mathrm{~g}$ of fermented solid. The mixture was stirred with magnetic agitation for $30 \mathrm{~min}$ at room temperature. Following this, the mixture was maintained in a hot water bath at $55{ }^{\circ} \mathrm{C}$ for $20 \mathrm{~min}$. The mixture was centrifuged at $3,000 \times \mathrm{g}$ during $5 \mathrm{~min}$ and $10 \mathrm{~mL}$ of supernatant was transferred to a tube. Three milliliters of water and $2 \mathrm{~mL}$ of hexane were added. After $1 \mathrm{~min}$ of agitation in Vortex mixer and separation of the layers, the upper layer (hexane) was transferred to another tube. This extraction process was repeated twice. The extracts were combined and evaporated with nitrogen stream and the dry extracts were dissolved in $2 \mathrm{~mL}$ of methanol. The ergosterol content in methanol solution was determined using an HPLC Varian equipped by autosampler (Basic-Marathon, Spark), isocratic pump (Varian 9002), and UV detector (Varian ProStar). The column was a reverse phase-C18 (Waters Spherisorb ODS2, 4.6 $\times 250 \mathrm{~mm}$ ). The mobile phase was methanol at a flow rate of $1 \mathrm{~mL} / \mathrm{min}$ and detection was made at $282 \mathrm{~nm}$. The ergosterol 
was identified by comparing retention times with ergosterol standard (from Sigma) and it was quantified by calibration curve.

\section{Results and Discussion}

\section{Selection of Fungi for Enzymes Production}

The aim of this study was to screen black Aspergillus fungi for enzyme production and to select the most efficient strains for the target enzymes. Different enzymatic tests were performed (proteolytic and lipolytic activity) with strains of A. niger, A. uvarum, A. ibericus, Aspergillus foetidus, and Aspergillus tubingensis. Table 1 shows the results of the assays carried out on solid media, in which enzymatic activity of fungal species was determined by measuring the diameter of halos formed by colonies in the agar plates after 5 days of growth.

All fungi presented lipolytic activity measured by Rhodamine B method using commercial olive oil as substrate because all showed an orange fluorescent halo. On the contrary, not all showed activity when tributyrine was used as substrate. Tributyrin assay is the most commonly used method for screening lipase production. However, tributyrin is not considered to be a true lipid as it disperses easily in water and can be cleaved by other esterases [27]. Fungal lipases showed higher substrate specificity for olive oil (long-chain triglycerides) than for tributyrin (short-chain triglycerides). Esterases and lipases are carboxylic ester hydrolases that catalyze both the hydrolysis and the synthesis of ester bonds. Esterases hydrolyze short-chain carboxylic acids, whereas lipases prefer long-chain acylglycerides [28]. Only some strains of A. niger, A. tubingensis, and A. uvarum showed moderate proteolytic activity.

Based on these preliminary data, A. niger MUM 03.58, A. ibericus MUM 03.49, and $A$. uvarum MUM 08.01 were selected for further studies, in addition A. uvarum and A. ibericus were selected because they are strains not studied on SSF.

\section{Screening of Substrate Composition for SSF Using a Plackett-Burman Design}

In this study, selected fungi were inoculated on winery and oil mill waste for production of enzymes by SSF. In initial tests, a poor growth of fungi on TPOMW was observed (data not shown). A similar behavior is found in several reported works. For example, A. niger exhibited slower growth on TPOMW than on sugar-beet waste and rice hulls [29]. Additionally, Aloui et al. [16] observed that $A$. niger was inhibited by TPOMW, but that mixtures of TPOMW with sugarcane bagasse clearly increased the fungal growth. This strong microbial inhibition is probably caused by the high initial concentration of phenolic compounds because also in composting processes of TPOMW, long composting periods are needed for this kind of material due to the presence of fats and phenols [30]. Further, it was observed that the addition of other wastes to TPOMW could stimulate growth of fungi and the production of enzymes in SSF processes because it could improve the transfer of oxygen and reduce toxicity [16]. In the present work, residues of the wine industry were selected to improve the fermentable characteristics of TPOMW in order to obtain higher yields of lipase.

To evaluate the effect of TPOMW mixture with other agro-industrial by-products in SSF, a Plackett-Burman experimental design was used. An experimental design for each microorganism was performed using 11 different fermentation conditions as shown in Table 2. This design allowed evaluating the main effect of EGM, VTS, OMWW, V, nutrients, urea addition, and time upon enzymes production by SSF. 
Lipases and proteases enzymes activities were determined in extracts. Table 2 presents enzyme activities detected in extract from SSF of the three selected fungal strains. In general, a wide variation can be observed in enzyme activities reported. This variation shows the influence of substrate composition and the importance of medium composition to attain a higher production of enzymes. Table 3 shows coefficients of regression and correlation coefficients $\left(R^{2}\right)$ of each design. Significant coefficients were identified by asterisk. Regression coefficients allow the determination of the effect of each constituent. A high value of regression coefficient indicates that a factor has a large impact on dependent variable. A $R^{2}$ close to 1 indicates a good correlation between the predicted response value and the actual response value. A possible curvature effect was included in the model.

The three tested strains (A. niger MUM 03.58, A. ibericus MUM 03.49, and A. uvarum MUM 08.01) showed lipolytic activity (Table 2), agreeing with previous solid agar tests (Table 1). A. ibericus was the most suitable fungus for lipase production by SSF. Maximum lipolytic activity was achieved in experiment 1 (14.83 U/g of dry substrate), followed by experiment 4 . This is the first report in literature about $A$. ibericus in SSF, although its potential as producer of lipases has already been demonstrated in $\mathrm{SmF}$ [4]. Falony et al. [31] studied lipase production by $A$. niger $\mathrm{J}-1$ by SSF of wheat bran; they achieved a maximum activity of $9.14 \mathrm{IU} / \mathrm{g}$ of dry substrate. Using crude olive oil cake as substrate in SSF, Candida utilis achieved a maximum activity of $14.5 \mathrm{U} / \mathrm{g}$ of dry substrate [14]. This value was increased through supplementation of the substrate with different carbon and nitrogen sources.

Figure 1a displays the main effect of each studied variable upon lipolytic activity in fermentation with $A$. ibericus. All supplements were positive, except for the addition of nutrients that had a negative effect. Urea was found to be the most influential variable in lipase production. Urea is a cheap source of nitrogen for microorganisms. A positive effect of urea in enzymes production have been observed in other works, the highest value of lipolytic activity by $A$. niger $\mathrm{J}-1$ was attained in the presence of urea [31]. An optimization study of chemical composition of medium found that urea was the best sole nitrogen source for lipase production by Candida lipolytica [32]. Additionally, a large fermentation time presented a clear positive effect on lipase production. EGM, VTS, and V showed a positive effect; EGM

Table 3 Regression coefficients and parameters of Plackett-Burman experimental design

\begin{tabular}{lllll}
\hline & Aspergillus niger & & Aspergillus ibericus & Aspergillus uvarum \\
\hline Terms & PA & LA & LA & LA \\
Constant & $1.691^{*}$ & $1.794^{*}$ & $7.505^{*}$ & $1.189^{*}$ \\
Curvature & $-0.587^{*}$ & $-0.991^{*}$ & $-3.982^{*}$ & $-0.532^{*}$ \\
EGM & $-0.072^{*}$ & $0.221^{*}$ & $1.683^{*}$ & $-0.277^{*}$ \\
VT & $0.202^{*}$ & $0.459^{*}$ & $0.748^{*}$ & $0.279^{*}$ \\
OMWW & $0.191^{*}$ & $0.669^{*}$ & $0.38^{*}$ & 0.067 \\
Vinasses & $0.199^{*}$ & $0.306^{*}$ & $1.415^{*}$ & $0.381^{*}$ \\
Nutrients & $0.352^{*}$ & $0.171^{*}$ & $-1.533^{*}$ & -0.161 \\
Urea & $0.181^{*}$ & $0.779^{*}$ & $2.528^{*}$ & $0.622^{*}$ \\
Time & $0.283^{*}$ & $0.551^{*}$ & $2.105^{*}$ & -0.088 \\
$\mathrm{R}^{2}$ & 0.99957 & 0.99939 & 0.99952 & 0.99460 \\
$\mathrm{R}^{2}$ corrected & 0.99786 & 0.99693 & 0.99760 & 0.97300 \\
\hline
\end{tabular}

$P A$ proteolytic activity, $L A$ lipolytic activity

*Significant coefficient at the $95 \%$ 

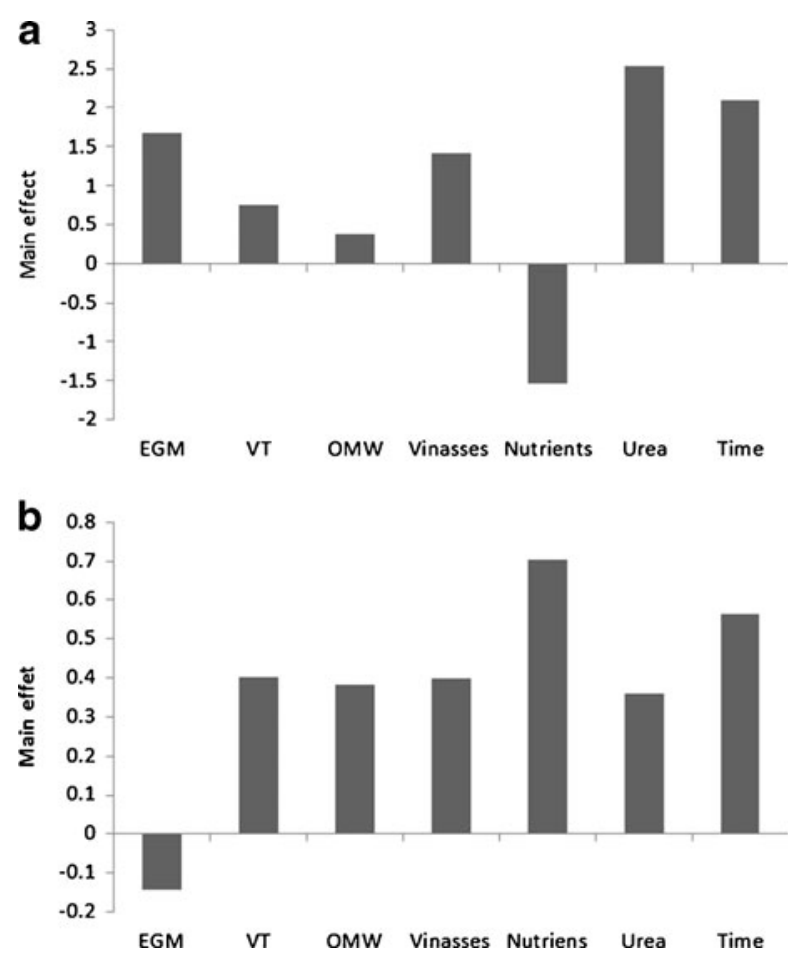

Fig. 1 The main effects of the substrate composition on a lipolytic activity from A. ibericus MUM 03.49; b protease activity from A. niger MUM 03.58. (significant at $95 \%$ ) by SSF at $75 \%$ of moisture and $25{ }^{\circ} \mathrm{C}$

was the supplemented waste with the highest effect on lipase production. Thus, the mixture of TPOMW with wineries wastes can lead to a reduction in production costs of lipases. OMWW presented a low effect on lipolytic activity; this waste generally contains variable quantities of residual olive oil, strictly depending on the extraction process efficiency [33]. Residual olive oil may favor the production of lipases [32]; nevertheless, the high inhibitory effect of phenolic compounds contained in OMWW may be the reason for the little effect on lipase production by SSF.

Proteases are one of the most important groups of industrial enzymes [34]. Only A. niger showed detectable protease activity, being the maximum activity attained in experiment 1 ( $3.03 \mathrm{U} / \mathrm{g}$ of dry substrate). Figure $1 \mathrm{~b}$ displays the main effects of studied variables. It can be concluded that protease activity was significant when TPOMW and VTS were used as solid substrates and nutritional supplements were added (OMWW, V, nutrients, and urea), whereas a negative effect of addition EGM was observed. In addition, maxima activities were detected when SSF were carried out during 14 days.

This can be an advantage when developing SSF processes since low proteolytic activity may avoid inactivation of other secreted enzymes and benefit the accumulation of those in the substrate, improving production yields.

Optimization of Lipase Production by Full Factorial Design $3^{2}$

Considering that urea and EGM were the variables with higher effect on lipase production by SSF of TPOMW according to the results of the Plackett-Burman experimental design. The 
Table 4 Full factorial $3^{2}$ design matrix to optimize urea and EGM addition for lipase production on SSF by $A$. ibericus

\begin{tabular}{|c|c|c|c|c|c|c|}
\hline \multirow[b]{3}{*}{ Experiment } & \multicolumn{4}{|c|}{ Independent variables } & \multicolumn{2}{|c|}{ Dependent variable } \\
\hline & \multicolumn{2}{|c|}{ Coded } & \multicolumn{2}{|c|}{ Uncoded } & \multirow{2}{*}{$\begin{array}{l}\text { Observed } \\
y_{1} \\
(\mathrm{U} / \mathrm{g})\end{array}$} & \multirow{2}{*}{$\begin{array}{l}\text { Predicted } \\
Y_{1} \\
(\mathrm{U} / \mathrm{g})\end{array}$} \\
\hline & $x_{1}$ & $x_{2}$ & $\begin{array}{l}X_{1} \\
(\mathrm{~g} / \mathrm{g})\end{array}$ & $\begin{array}{l}X_{2} \\
(\% \text { EGM) }\end{array}$ & & \\
\hline 1 & -1 & -1 & 0.01 & 25 & $9.31 \pm 0.21$ & 9.30 \\
\hline 2 & -1 & 0 & 0.01 & 50 & $8.56 \pm 0.43$ & 8.56 \\
\hline 3 & -1 & 1 & 0.01 & 75 & $9.46 \pm 0.37$ & 9.46 \\
\hline 4 & 0 & -1 & 0.055 & 25 & $18.73 \pm 0.54$ & 18.73 \\
\hline 5 & 0 & 0 & 0.055 & 50 & $18.94 \pm 0.65$ & 18.25 \\
\hline 6 & 0 & 1 & 0.055 & 75 & $18.22 \pm 0.62$ & 18.22 \\
\hline 7 & 1 & -1 & 0.1 & 25 & $18.65 \pm 0.45$ & 18.65 \\
\hline 8 & 1 & 0 & 0.1 & 50 & $17.25 \pm 0.23$ & 17.25 \\
\hline 9 & 1 & 1 & 0.1 & 75 & $19.15 \pm 0.68$ & 19.15 \\
\hline 10 & 0 & 0 & 0.055 & 50 & $18.40 \pm 0.34$ & 18.25 \\
\hline 11 & 0 & 0 & 0.055 & 50 & $17.40 \pm 0.32$ & 18.25 \\
\hline
\end{tabular}

$X_{1}$ urea (uncoded), $X_{2}$ exhausted grape mark, $y_{1}$ lipase activity, $g$ grams of dry substrate

medium composition for production of lipases by A. ibericus was optimized using a three-level factorial design, which studied two factors in nine runs with additional two central points, linear and quadratics interactions were taken into account in the model. The range of variation of urea was set from 0.01 to $0.1 \mathrm{~g} / \mathrm{gds}$ and the EGM varied from 25 to $75 \%$ of dry substrate. Fermentation conditions were the same as in the previous design. The enzyme extractions were carried out at 14 days of fermentation. Table 4 shows the predicted response by the model $\left(Y_{1}\right)$ and experimental data observed in experiments $\left(y_{1}\right)$. As it can be seen, no significant differences between the model predicted and observed data were found. Table 5 lists regression coefficients and their statistical significance (based on a $t$ test) as well as the statistical parameters, which measure the goodness of model. The Fisher test $(F)$ can show better fit of

Table 5 Regression coefficients and parameters of the full factorial design $\left(3^{2}\right)$

\begin{tabular}{|c|c|c|c|c|c|}
\hline Model term & \multicolumn{2}{|c|}{ Regression coefficients } & Standard error & $T$ & $P$ \\
\hline Constant & \multicolumn{2}{|l|}{18.2465} & 0.4496 & 40.5879 & 0.0006 \\
\hline$x_{1}$ & \multicolumn{2}{|l|}{4.3443} & 0.5506 & 7.8902 & 0.0157 \\
\hline$x_{1}^{2}$ & \multicolumn{2}{|l|}{-5.3424} & 0.7108 & -7.5159 & 0.0172 \\
\hline$x_{2}$ & \multicolumn{2}{|l|}{-0.2528} & 0.5506 & -0.4591 & 0.6912 \\
\hline$x_{2}{ }^{2}$ & \multicolumn{2}{|l|}{0.2266} & 0.7108 & 0.3188 & 0.7801 \\
\hline$x_{1} \cdot x_{2}$ & \multicolumn{2}{|l|}{0.0854} & 0.3893 & 0.2194 & 0.8467 \\
\hline$x_{1} \cdot x_{2}^{2}$ & \multicolumn{2}{|l|}{0.4168} & 0.6743 & 0.6180 & 0.5996 \\
\hline$x_{1}^{2} \cdot x_{2}$ & \multicolumn{2}{|l|}{0.4157} & 0.6743 & 0.6165 & 0.6004 \\
\hline$x_{1}^{2} \cdot x_{2}^{2}$ & \multicolumn{2}{|l|}{1.0093} & 0.9798 & 1.0301 & 0.4112 \\
\hline Dependent variable & $R$ & $R^{2}$ & $R_{\text {Adj }}^{2}$ & $F$ & Significance level \\
\hline$y_{1}$ & 0.9968 & 0.9936 & 0.9681 & 38.9073 & 97.47 \\
\hline
\end{tabular}

$P$ probability, $R$ multiple correlation coefficient, $R^{2}$ coefficient of determination 


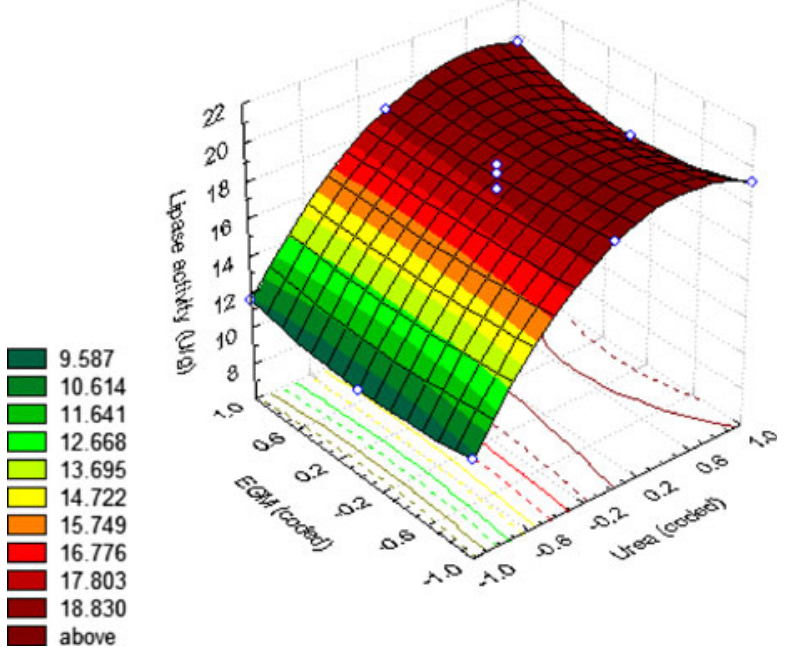

Fig. 2 Response surface for lipolytic activity as a function of the urea (coded) and EGM (coded)

the model, $F_{\text {cal }}>F_{\text {tab }}(38.9073>19.371)$, the higher value of $F$ demonstrated a good fit. The significance level obtained by critic value of $F$ was $97.47 \%$. The determination coefficient $\left(R^{2}\right)$ was 0.9936 , which demonstrated that a satisfactory adjustment of the model, and indicating that $99 \%$ of the variability in the response could be explained by the model.

Three-dimensional response surface curve plot allows determining the interaction of the independent variables and the optimum levels that have the most significant effect on dependent variable. Figure 2 describes the effect of urea and EGM on lipase production when added to TPOMW. It can be seen that the lipase activity increased gradually with the increase of urea until it reaches a certain value, after which lipase activity began to descend. Contrariwise, EGM has no effect on lipase activity. This observation can also be seen in

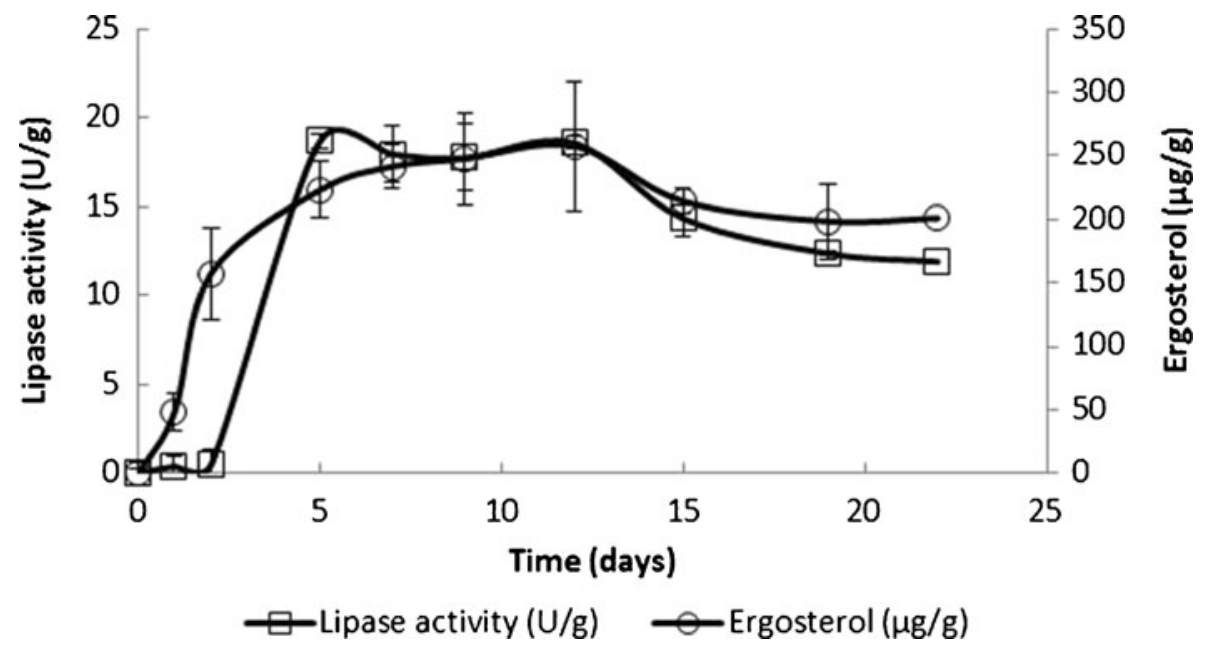

Fig. 3 Lipase production by $A$. ibericus MUM 03.49 and estimated biomass by ergosterol content in experiment with optimal conditions $\left(0.073 \mathrm{~g}\right.$ urea/g and $25 \%$ of EGM) under SSF at $75 \%$ of moisture and $25{ }^{\circ} \mathrm{C}$ 
Table 5, where urea is the only factor showing regression coefficients of linear and quadratic terms with significant effect at $95 \%$.

Using the "solver" application of Microsoft Excel, the maximum lipase activity predicted by model was determined. Under the best conditions, $19.85 \mathrm{U} / \mathrm{g}$ was obtained mixing TPOMW with $0.073 \mathrm{~g}$ urea $/ \mathrm{g}$ and $25 \%$ of EGM. This value is higher than the maximum activity achieved in Plackett-Burman design $(14.84 \mathrm{U} / \mathrm{g})$. Thus, the full factorial design allowed improving the lipase production. To validate the model, an experiment at the best conditions was planned. In this study, the enzymes activity and ergosterol content during several days were evaluated and their values were represented in Fig. 3. Ergosterol is a component of fungal cell membranes that can be used to quantify fungal growth in SSF [35]. It can be observed that at the beginning of fermentation the concentration of ergosterol was increasing even if no lipase activity was detected during the first 2 days. On the fifth day, the maximum lipase activity was achieved and it was maintained up to 12 days. After that, the activity slightly decreased, most probably due to proteolysis. The maximum activity reached was $18.67 \mathrm{U} / \mathrm{g}$, which is similar to the theoretical value predicted by the model $(19.85 \mathrm{U} / \mathrm{g})$.

\section{Conclusions}

A. ibericus MUM 03.49, A. niger MUM 03.58, and A.uvarum MUM 08.01 were selected as suitable microorganisms to produce lipase on SSF.

The effect of substrate type on lipase production has been observed, which was stimulated by adding EGM and urea to TPOMW. A. ibericus demonstrated to be the best producer of lipase by SSF.

The optimization of substrate composition for lipase production $(0.073 \mathrm{~g}$ urea/g and $25 \%$ of EGM) by A. ibericus allowed increasing the lipolytic activity to $18.67 \mathrm{U} / \mathrm{g}$. The results herein reported may have potential application on the simultaneous management and valorization of olive mill and wineries wastes.

Acknowledgments José Manuel Salgado is grateful for Postdoctoral fellowship (EX-2010-0402) of Education Ministry of Spanish Government. Luís Abrunhosa was supported by the grant SFRH/BPD/43922/2008 from Fundação para a Ciência e Tecnologia_FCT, Portugal. Authors thank Fundação para a Ciência e a Tecnologia (FCT) for financial support through the project FCT Pest-OE/EQB/LA0023/2011.

\section{References}

1. Morillo, J. A., Antizar-Ladislao, B., Monteoliva-Sánchez, M., Ramos-Cormenzana, A., \& Russell, N. J. (2009). Applied Microbiology and Biotechnology, 82, 25-39.

2. Assas, N., Ayed, L., Marouani, L., \& Hamdi, M. (2002). Process Biochemistry, 38, 361-365.

3. Haagensen, F., Skiadas, I. V., Gavala, H. N., \& Ahring, B. K. (2009). Biomass and Bioenergy, 33, 16431651 .

4. Abrunhosa, L., Oliveira, F., Dantas, D., Gonçalves, C., \& Belo, I. (2013). Bioprocess and Biosyst Eng, 36, 285-291.

5. de la Casa, J. A., Romero, I., Jiménez, J., \& Castro, E. (2012). Ceramics Int., 38, 5027-5037.

6. Bustamante, M. A., Moral, R., Paredes, C., Pérez-Espinosa, A., Moreno-Caselles, J., \& Pérez-Murcia, M. D. (2008). Waste manage, 28, 372-380.

7. Eusébio, A., Mateus, M., Baeta-Hall, L., Almeida-Vara, E., \& Duarte, J. C. (2005). Water Science and Technology, 51, 107-112. 
8. Pandey, A. (2003). Biochemical Engineering Journal, 13, 81-84.

9. Chakradhar, D., Javeed, S., \& Sattur, A. P. (2009). J. Ind. Microbiol. Biot., 36, 1179-1187.

10. Pérez-Guerra, N., Torrado-Agrasar, A., López-Macias, C., \& Pastrana, L. (2003). Electronic Journal of Agricultural Food chemistry, 2, 343-350.

11. Gutarra, M. L. E., Cavalcanti, E. D. C., Castilho, L. R., Freire, D. M. G., \& Santanna, G. L., Jr. (2005). Applied Biochemistry and Biotechnology, 121-124, 105-116.

12. Chen, L., Yang, X., Raza, W., Luo, J., Zhang, F., \& Shen, Q. (2011). Bioresource Technology, 102, 39003910.

13. Cordova, J., Nemmaoui, M., Isma1 li-Alaoui, M., Morin, A., Roussos, S., Raimbault, M., \& Benjilali, B. (1998). J. Mol. Catal. B-Enzym, 5, 75-78.

14. Moftah, O. A. S., Grbavčić, S., Zuža, M., Luković, N., Bezbradica, D., \& Knežević-Jugović, Z. (2012). Applied Biochemistry and Biotechnology, 166, 348-364.

15. Hegedus, D. D., \& Khachatourians, G. G. (1988). Biotechnology Letters, 10, 637-642.

16. Aloui, F., Abid, N., Roussos, S., \& Sayadi, S. (2007). Biochemical Engineering Journal, 35, 120-125.

17. Giannoutsou, E. P., Katsifas, E. A., Geli, A., \& Karagouni, A. D. (2012). World Journal of Microbiology and Biotechnology, 28, 849-856.

18. Vishwanatha, K. S., Apu-Rao, A. G., \& Singh, S. A. (2010). Journal of Industrial Microbiology and Biotechnology, 37, 129-138.

19. Perrone, G., Varga, J., Susca, A., Frisvad, J. C., Stea, G., Kocsubé, S., Tóth, B., Kozakiewicz, Z., \& Samson, R. A. (2008). International Journal of Systematic and Evolutionary Microbiology, 58, 1032-1039.

20. Delabona, P. S., Pirota, R. D. P. B., Codima, C. A., Tremacoldi, C. R., Rodrigues, A., \& Farinas, C. S. (2013). Ind Crops Prod, 42, 236-242.

21. Gopinath, S. C. B., Anbu, P., \& Hilda, A. (2005). Mycoscience, 46, 119-126.

22. Serra, R., Cabañes, F. J., Perrone, G., Castellá, G., Venâncio, A., Mulè, G., \& Kozakiewicz, Z. (2006). Mycologia, 98, 295-306.

23. Kouker, G., \& Jaeger, K. (1987). Applied and Environmental Microbiology, 53, 211-213.

24. Gomes, N., Gonçalves, C., García-Román, M., Teixeira, J. A., \& Belo, I. (2011). Analytical Methods, 3 , 1008-1013.

25. Charney, J., \& Tomarelli, M. (1947). The Journal of Biological Chemistry, 171, 501-505.

26. Mar, S., Morales, H., Ramos, A. J., \& Sanchis, V. (2006). Society, 1474, 1468-1474.

27. Jarvis, G. N., \& Thiele, J. H. (1997). Journal of Microbiological Methods, 29, 41-47.

28. Kim, J. T., Kang, S. G., Woo, J. H., Lee, J. H., Jeong, B. C., \& Kim, S. J. (2007). Applied Microbiology and Biotechnology, 74, 820-828.

29. Vassilev, N., Baca, M. T., Vassileva, M., Franco, I., \& Azcon, R. (1995). Applied Microbiology and Biotechnology, 44, 546-549.

30. Cayuela, M. L., Sánchez-Monedero, M. A., \& Roig, A. (2010). Biodegradation, 21, 465-473.

31. Falony, G., Armas, J. C., Mendoza, J. C. D., \& Hernández, J. L. M. (2006). Food Technology and Biotechnology, 44, 235-240.

32. Ali, S., \& Rafi, H. (2010). Engineering in Life Science, 10, 465-473.

33. Crognale, S., D’Annibale, A., Federici, F., Fenice, M., Quaratino, D., \& Petruccioli, M. (2006). Journal of Chemical Technology and Biotechnology, 81, 1547-1555.

34. Rodríguez-Couto, S. (2008). Biotechnology Journal, 3, 859-870.

35. Han, J. R., An, C. H., \& Yuan, J. M. (2005). Journal of Applied Microbiology, 99, 910-915. 